\title{
Active rock glaciers as shallow groundwater reservoirs, Austrian Alps
}

\author{
Thomas Wagner $^{1}$ (D) $\cdot$ Alexander BrodaCz ${ }^{1,3} \cdot$ Karl Krainer $^{2} \cdot$ Gerfried Winkler $^{1}$
}

Received: 15 October 2019 / Revised: 30 January 2020 / Published online: 19 June 2020

(c) The Author(s) 2020

\begin{abstract}
Rock glaciers are the most prominent landforms of alpine permafrost and comprise complex shallow aquifer systems in (high) alpine catchments. Recession analyses of groundwater discharge of four active rock glaciers that contain permafrost ground ice show that they have a base flow component of the order of a few liters per second, similar to that of a relict rock glacier in which permafrost ground ice is absent. This is related to an unfrozen (fine-grained) base layer with a thickness of about $10 \mathrm{~m}$. Based on a threshold analysis of precipitation events and event water discharge, depressions atop the bedrock or the permafrost table seem to play only a minor role in storing groundwater. This important finding has rarely been documented, but is highly relevant for optimal groundwater resources management in sensitive (high) alpine catchments and ecosystems. All the rock glaciers analyzed here are located in the Austrian Alps and represent the nationwide sites where suitable discharge data are available. The analysis highlights the hydrogeological importance of these discrete permafrost-derived debris accumulations as complex shallow groundwater bodies with important—but limited-storage and buffer capabilities.
\end{abstract}

Keywords Rock glacier $\cdot$ Base flow $\cdot$ Recession analysis $\cdot$ Groundwater storage capacity $\cdot$ Permafrost

\section{Aktive Blockgletscher als seichte Grundwasserspeicher der österreichischen Alpen}

\section{Zusammenfassung}

Blockgletscher zählen zu den markantesten Landschaftsformen des alpinen Permafrosts und beinhalten komplexe, seichte Grundwasserleiter in (hoch-) alpinen Einzugsgebieten. Analysen des Auslaufverhaltens von vier intakten Blockgletschern, die Permafrosteis enthalten, zeigen, dass diese einen relevanten Basisabfluss in der Größenordnung von einigen Litern pro Sekunde besitzen, vergleichbar mit dem eines reliktischen Blockgletschers, der kein Permafrosteis mehr enthält. Dies wird mit einer ungefrorenen (feinkörnigen) Basisschicht mit einer Mächtigkeit von etwa $10 \mathrm{~m}$ in Verbindung gebracht. Basierend auf einer Schwellenwertanalyse von Niederschlagsereignissen und Ereigniswasserabfluss scheinen Senken/Vertiefungen im Festgesteins bzw. der Permafrosttafel nur eine untergeordnete Rolle bei der Grundwasserspeicherung zu spielen. Dies ist eine wichtige Erkenntnis, die bis jetzt nur selten dokumentiert werden konnte, jedoch für eine optimale Grundwasserressourcenplanung in sensiblen (hoch-) alpinen Einzugsgebieten bzw. Ökosystemen höchst relevant ist. Die hier analysierten Blockgletscher befinden sich alle in den Österreichischen Alpen und repräsentieren die nationalen Standorte, für die brauchbare Abflussdaten zur Verfügung stehen. Die Analysen unterstreichen die hydrogeologische Relevanz dieser diskreten Permafrost-bezogenen Schuttkörper als komplexe, seichte Grundwasserkörper, welche eine wichtige - wenn auch limitierte - Speicher- und Puffereigenschaften aufweisen.

\section{Thomas Wagner \\ thomas.wagner@uni-graz.at}

Alexander Brodacz

alexander.brodacz@zt-neubauer.at

Karl Krainer

karl.krainer@uibk.ac.at

Gerfried Winkler

Gerfried.winkler@uni-graz.at
1 Institute of Earth Sciences, NAWI Graz Geocenter, University of Graz, Heinrichstr. 26, 8010 Graz, Austria

2 Institute of Geology, University of Innsbruck, Innrain 52, 6020 Innsbruck, Austria

3 Mag. Erhard Neubauer ZT GmbH, Kalvarienbergstr. 76-78, 8020 Graz, Austria 


\section{Introduction}

The impact of climate warming on glacier retreat in mountainous regions of the world and their runoff has been a subject of intense research during recent decades (e.g. Neal et al. 2010; Huss 2011; Huss and Hock 2018; Shannon et al. 2019). By the end of the century, the glacial ice volume loss is expected to be about $77 \%$ for the Central European Alps. When considering only the mountainous regions below $4000 \mathrm{~m}$ a.s.l., an almost complete loss is to be expected (Shannon et al. 2019). While a lot of research deals with the impact of climate change on glaciers and related runoff characteristics, knowledge about the runoff behavior of permafrost affected landforms such as rock glaciers is still scarce (e.g. Geiger et al. 2014; Rogger et al. 2017). Research of the last two decades suggests the global importance of rock glaciers as fresh water resources and their impact on the runoff of alpine headwaters (Jones et al. 2018; 2019, and references therein). Following the expectation that most of the glaciers will disappear by the end of the century in mountainous regions, permafrost, and particularly rock glaciers as their most prominent landforms, will likely gain in importance in the mountain cryosphere and become even more important for ecosystem services provision (Grêt-Regamey et al. 2012; Harrington et al. 2017). This is to be anticipated, because permafrost ground ice in rock glaciers, which is protected by a thick debris layer, is melting at much smaller rates compared to ice glaciers (Jones et al. 2019).

Rock glaciers can be classified into intact and relict rock glaciers, i.e. into rock glaciers with and without permafrost ground ice (e.g. Barsch 1996). A further subclassification of intact rock glaciers into active and inactive is based on the fact, that the former still creep downslope, the latter do not show any movement. A conceptual understanding of the internal layered structure of relict and intact rock glaciers is reported in several studies (Giardino et al. 1992; Hausmann et al. 2007, 2012; Zurawek 2002; Winkler et al. 2018; Jones et al. 2019). In these complex landforms water is stored and transmitted in different ways over different time scales. Short, intermediate, and long-term storage has to be considered (Jones et al. 2018, 2019).

Concerning the hydrogeology, differences in the discharge pattern between relict and intact rock glaciers are expected, as the permafrost body in intact rock glaciers should have an influence on the runoff pattern and typically the mean (catchment) elevation is higher. Winkler et al. (2016) demonstrated the complex flow and storage behavior of a relict rock glacier that is related to its internal structure, including a fast and a delayed flow component or short and long-term storage, respectively. The fast flow component is related to the coarse-grained debris layer of the relict rock glacier (e.g. Pauritsch et al. 2017). The long-term ground- water storage is supposed to be provided by a fine-grained basal layer (Winkler et al. 2016). Within intact rock glaciers preferential flow paths for the fast flow component might occur mainly on top of the frozen permafrost body (Krainer et al. 2007) and/or infiltrating water percolates through the permafrost layer that is not considered as a strict barrier but contains gaps and fractures (Harrington et al. 2018). During dry periods in summer, active rock glaciers often provide spring runoff derived from snow melt in early summer, ice melt from ice glaciers within the rock glacier catchments, from potential melt of permafrost ground ice or groundwater contribution in late summer (Krainer and Mostler 2002; Krainer et al. 2007). During winter periods when little to no recharge occurs due to low temperatures and solid precipitation (snow), discharge at springs of active (or intact in general) rock glaciers is mainly fed by groundwater (Winkler et al. 2018, Fig. 2b). Although (semi-) quantitative interpretations of the fast flow components of active rock glaciers exist (e.g. Krainer and Mostler 2002; Krainer et al. 2007), analysis of the groundwater contribution (base flow) of intact rock glaciers is rare (Harrington et al. 2017, 2018; Liu et al. 2004; Williams et al. 2006).

The groundwater contribution is assumed to be related to the existence of an unfrozen, fine-grained sediment layer between the bedrock and the permafrost body of intact rock glaciers (e.g. Burger et al. 1999), that was determined by surface geophysical investigations (Hausmann et al. 2007, 2012) and drilling (Krainer et al. 2015). In addition, Harrington et al. (2018) discussed the potential impact of the bedrock topography below the rock glacier on the longterm storage related to the fill-spill mechanism (Tromp-van Meerveld and McDonnell 2006). However, the actual quantitative groundwater contribution of the basal fine-grained sediment layer, which provides the base flow during winter (or during summer droughts), is still poorly understood. Certainly, because winter base flow often cannot be monitored as rock glacier springs or the related gauging stations freeze up in wintertime (Krainer and Mostler 2002). Thus, the intermediate to long-term groundwater storage within the unfrozen base layer still needs to be quantified.

The aims of this contribution are: i) to show if there is a potentially important base flow derived from the subpermafrost unfrozen layer in active rock glaciers, ii) to determine if differences exist between the drainage system/ pattern of the base flow of active and relict rock glaciers or not, and iii) to quantify the groundwater storage capacity of active rock glaciers. The latter is important, as a certain maximum volume of water might be stored in the basal unfrozen layer of a rock glacier and any additional water will be transferred rather quickly through it by lateral flow, reducing the landforms buffer capabilities. Here we present a first base flow analysis of four active rock glaciers to provide evidence that active rock glaciers might have a relevant 


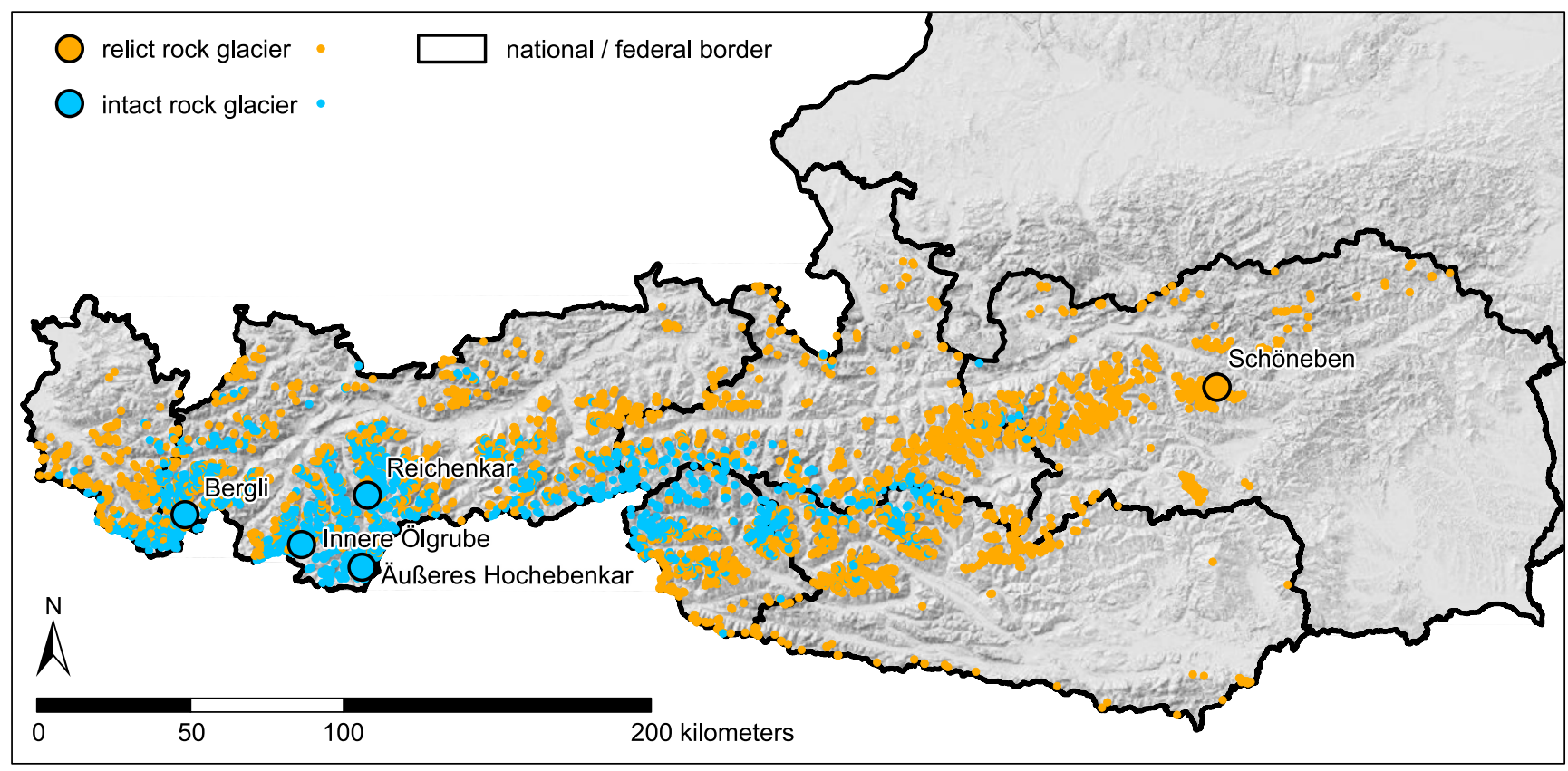

Fig. 1 Overview of rock glaciers mapped in the Austrian Alps and the five test sites analyzed. Rock glaciers are shown as centroid points within the Austrian national border distinguishing between relict and intact rock glaciers (Wagner et al., accepted). Bergli (Silvretta Mountain Group), Innere Ölgrube and Äußeres Hochebenkar (Ötztal Alps); Reichenkar (Stubai Alps) and Schöneben rock glacier (Seckauer Tauern Range)

Abb. 1 Übersichtsdarstellung der ausgewiesenen Blockgletscher in den Österreichischen Alpen sowie der fünf analysierten Untersuchungsgebiete. Blockgletscher sind als Zentroidpunkte innerhalb der Österreichischen Grenze dargestellt, wobei zwischen reliktischen und intakten Blockgletschern unterschieden wird (Wagner et al., akzeptiert). Bergli (Silvretta), Innere Ölgrube und Äußeres Hochebenkar (Ötztaler Alpen); Reichenkar (Stubaier Alpen) und Schöneben Blockgletscher (Seckauer Tauern)

base flow during winter and further constitute a groundwater contribution to streamflow of interest for water management issues.

\section{Study areas}

Discharge data of four active rock glaciers in Tyrol/Austria and - for comparison - of a relict rock glacier in Styria/ Austria were analyzed. The test sites were chosen based on the requirements of available discharge data over a time period of at least three years and that the entire watershed is drained by a spring (or springs) at the front of the rock glacier (i.e. no significant unquantifiable subsurface outflow through the debris). Discharge was measured at gauging stations that were installed close to the rock glacier front at a distance of a few tens of meters downstream from the rock glacier spring. Fig. 1 shows an overview of all rock glaciers mapped in the Austrian Alps (Wagner et al. in press) and the test sites used in this study that are marked separately. Field impressions of the individual rock glaciers and a location map including the location of the gauging stations and the related catchment areas are presented in Fig. 2.

Some of the general properties of the investigated rock glaciers are listed in Table 1 for a direct comparison. A more detailed description of the individual rock glaciers is given below.

\section{Schöneben (SRG)}

The relict rock glacier Schöneben is located in the Seckauer Tauern Range of Styria in a northeast-facing cirque (Fig. 2a). This tongue shaped rock glacier extends from $1715 \mathrm{~m}$ a.s.l. to $1912 \mathrm{~m}$ a.s. 1 . with a length of $746 \mathrm{~m}$. The rock glacier covers an area of $\sim 0.11 \mathrm{~km}^{2}$ and its catchment area (including the rock glacier itself) measures $\sim 0.67 \mathrm{~km}^{2}$ with a mean elevation of the catchment of $2022 \mathrm{~m}$ a.s.l. The bedrock of the catchment area consists of gneissic rocks of the Silvretta-Seckauer nappe system (e.g. Pfingstl et al. 2015). A layered internal structure was determined by surface geophysical methods (ground penetrating radar (GPR), seismic refraction). The rock glacier is composed of a coarse, blocky surface layer with a thickness of several meters, a fine to coarse-grained main layer up to several tens of meters thick (former permafrost layer), and a base layer of fine-grained material with a thickness of up to $15 \mathrm{~m}$ (Winkler et al. 2016; Pauritsch et al. 2017). The rock glacier and its entire catchment is drained by one spring at the front of the rock glacier, which is included in the official spring network of the Hydrographic Service of Styria (HZB Nr. 396762). The water height is continuously mon- 


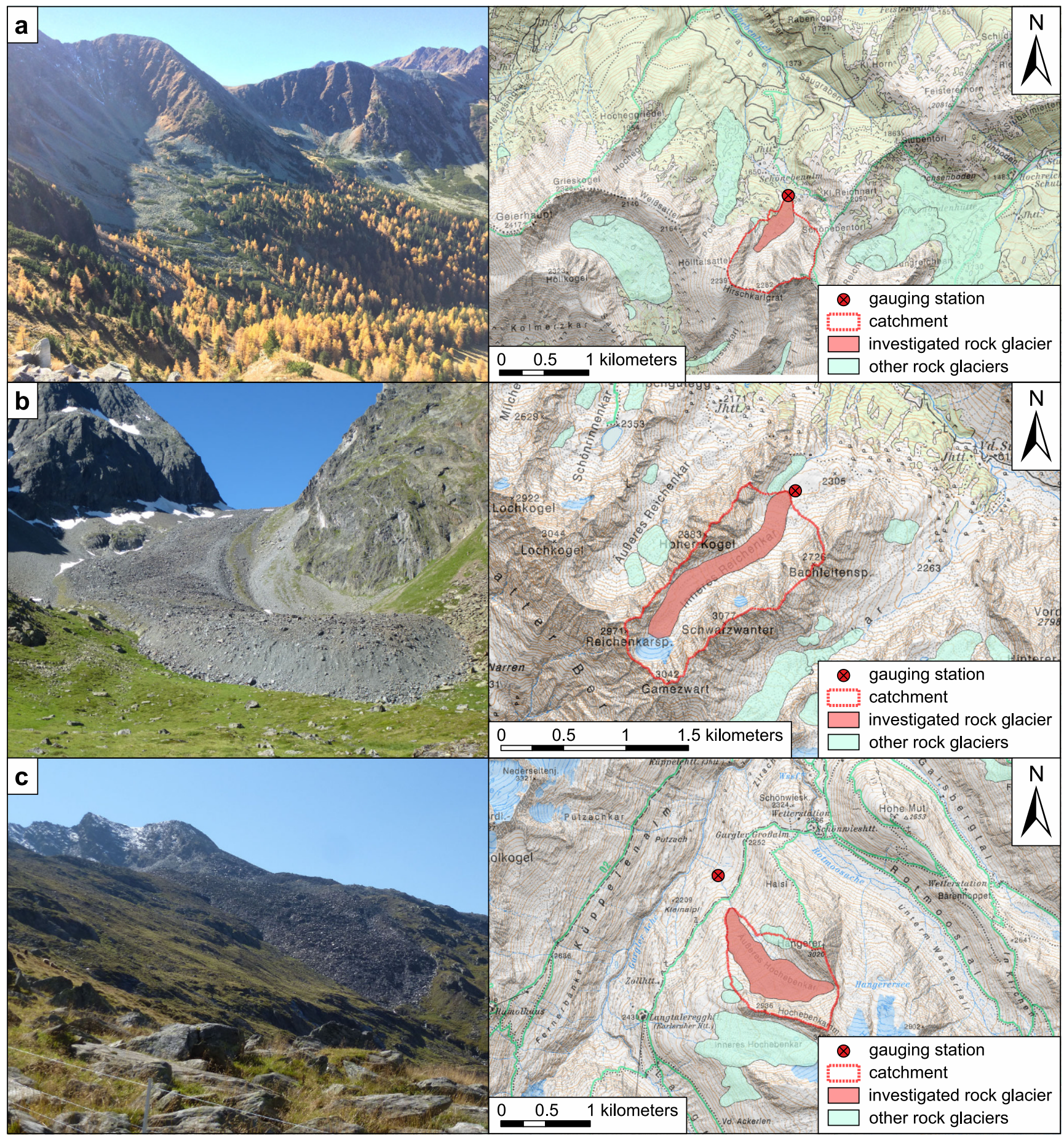

Fig. 2 Field impressions and locations of the investigated rock glaciers, their catchments, and gauging stations: a Schöneben, b Reichenkar, and c Äußeres Hochebenkar (modified after Brodacz 2019)

Abb. 2 Geländeeindrücke und Lage der untersuchten Blockgletscher, deren Einzugsgebiete und Pegelmessstellen: a Schöneben, b Reichenkar, und c Äußeres Hochebenkar (modifiziert nach Brodacz 2019) 


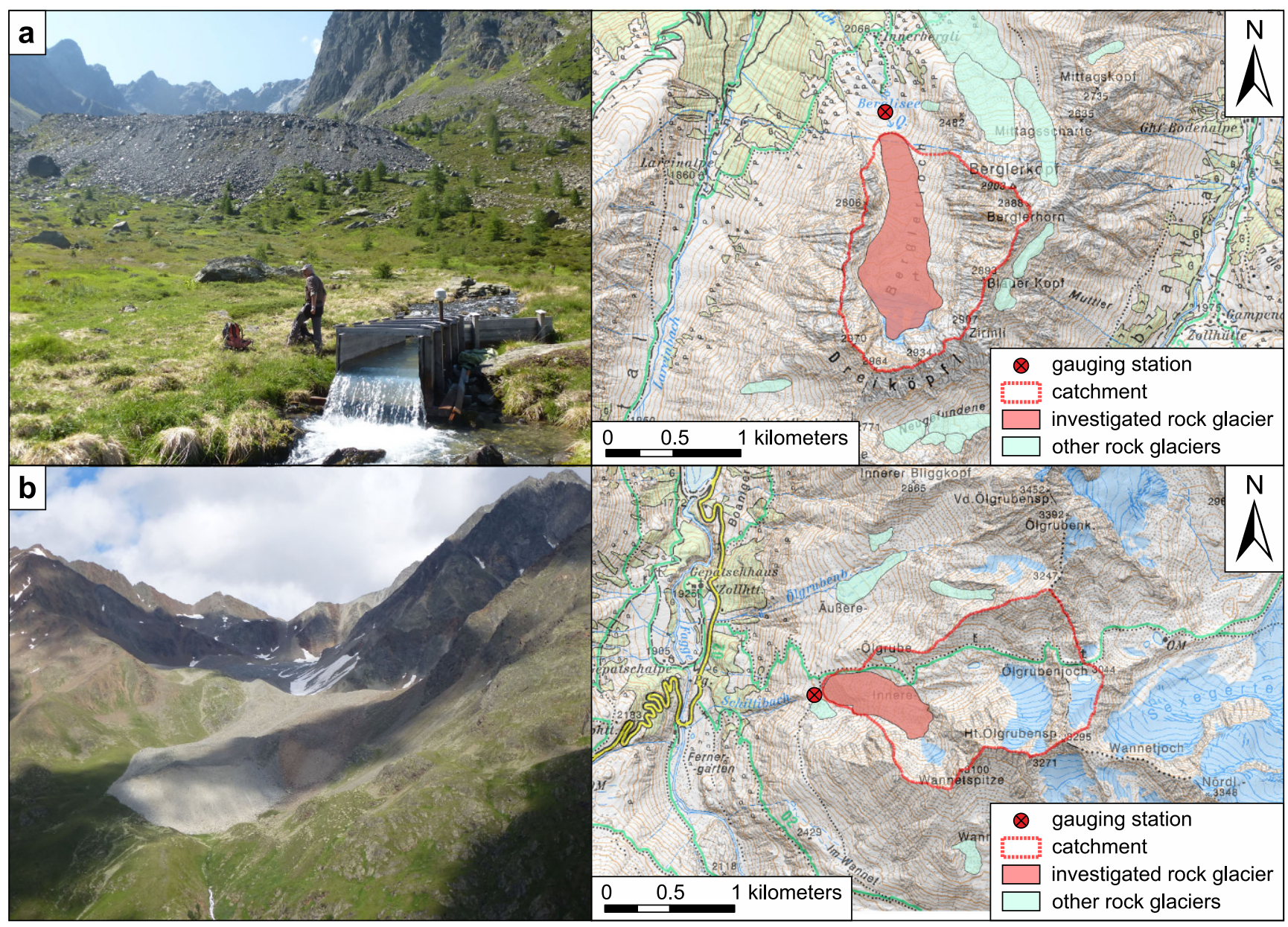

Fig. 3 Field impressions and locations of the investigated rock glaciers, their catchments, and gauging stations: a Bergli and b Innere Ölgrube (modified after Brodacz 2019)

Abb. 3 Geländeeindrücke und Lage der untersuchten Blockgletscher, deren Einzugsgebiete und Pegelmessstellen: a Bergli und b Innere Ölgrube (modifiziert nach Brodacz 2019)

itored at a rectangular weir about $40 \mathrm{~m}$ downstream of the rock glacier front since 2002 (Winkler et al. 2016). In December 2011, an automatic weather station (S-AWS) was installed on the rock glacier to provide data about input parameters (i.a. precipitation; Winkler et al. 2016).

\section{Reichenkar (RK)}

The Reichenkar rock glacier is one of the most active rock glaciers of the Austrian Alps (Fig. 2b). This tongue-shaped rock glacier is located in a northeast-trending small side valley of Sulztal, in the western Stubai Alps. Bedrock of the catchment is mainly amphibolite and eclogite; in the lower part of this side valley biotite-plagioclase-gneiss. Debris of the rock glacier is mostly composed of amphibolite, subordinately of eclogite and gneiss.

The rock glacier is $1641 \mathrm{~m}$ long, up to $194 \mathrm{~m}$ wide, and covers an area of $0.28 \mathrm{~km}^{2}$. The steep front of the rock glacier terminates at an elevation of $2295 \mathrm{~m}$, the rooting zone is at $2783 \mathrm{~m}$. The north facing cirque above the rooting zone is still occupied by a small cirque glacier (Reichenkar Ferner; $\sim 0.01 \mathrm{~km}^{2}$ ). The gradient of the steep, unvegetated, and very active front measures $\sim 40^{\circ}$. The surface of the rock glacier displays a typical topography of transverse and longitudinal furrows and ridges (Krainer and Mostler 2000). A rock glacier spring is present at the base of the steep front where all the water of the rock glacier and its catchment $\left(1.17 \mathrm{~km}^{2}\right)$ is released. In 1998 a gauging station was installed approximately $70 \mathrm{~m}$ downstream from the front of the rock glacier (Krainer and Mostler 2002; Krainer et al. 2007). This station was destroyed by the advancing front of the rock glacier in 2017 (and represents the end of available discharge data). The rock glacier is characterized by high flow velocities of up to three m/year near the front (Krainer and Mostler 2006).

Geophysical data from GPR, seismic, and gravimetric surveying show that the lower part of the rock glacier is composed of an active, unfrozen surface layer with an av- 
erage thickness of five metres, underlain by the permafrost body which is about $25 \mathrm{~m}$ thick and contains $45-60 \%$ ice. The upper part the rock glacier contains massive ice ("icecored"; Krainer et al. 2002). Between the bedrock and the permafrost body an unfrozen fine-grained sediment layer was detected, which is a few $\mathrm{m}$ thick (Hausmann et al. 2007).

A weather station near the Reichenkar rock glacier is not available. The nearest stations are Umhausen and Obergurgl. Both of them are located at a distance of more than $10 \mathrm{~km}$ and are not representative.

\section{Äußeres Hochebenkar (AHK)}

The Äußeres Hochebenkar rock glacier is one of the largest and most active rock glaciers in the Austrian Alps (Fig. 2c). The rock glacier is located in a northwest-facing cirque in the southern part of the Ötztal Alps. Bedrock of the catchment consists of paragneiss and mica schists of the so called Ötztal-Stubai Metamorphic Complex (Hoinkes and Thöni 1993). The tongue-shaped rock glacier extends from the steep front with its base at an elevation of $2352 \mathrm{~m}$ to the rooting zone at an elevation of $2849 \mathrm{~m}$. The rock glacier is $1442 \mathrm{~m}$ long and up to $541 \mathrm{~m}$ wide in the upper part. The rock glacier covers an area of $0.48 \mathrm{~km}^{2}$, the drainage area measures approximately $1.03 \mathrm{~km}^{2}$.

The surface debris layer is coarse-grained with an average grain-size of $0.35-0.58 \mathrm{~m}$ and individual blocks up to several metres in diameter. The surface of the rock glacier shows well-developed transverse, in the upper part also longitudinal ridges and furrows.

At the base of the steep front, several springs occur at which the bulk of the meltwater of the rock glacier is released. A minor amount of water flows off at a rock glacier spring on the eastern margin at an elevation of $2525 \mathrm{~m}$. A gauging station was installed at a distance of $320 \mathrm{~m}$ from the front of the rock glacier at an elevation of $2230 \mathrm{~m}$, which belongs to the official spring network of the Hydrographic Service of Tyrol (HZB Nr. 396283). Flow velocities of the rock glacier are recorded since 1938 (see Nickus et al. 2015; and references therein; Krainer 2015).

For the AHK, the weather station of Obergugl, $(\sim 4 \mathrm{~km}$ $\mathrm{NE}$ of the rock glacier) is used to quantify precipitation input over the observation period.

\section{Bergli (BER)}

The active rock glacier Bergli is located in the Silvretta Mountain Group in western Tyrol, in a north-facing cirque. Bedrock of the catchment area of this rock glacier is composed of mainly quartzitic gneiss, in the southern part (above the rooting zone) of amphibolite and migmatites (Wagner et al. 2019). The rock glacier is $1545 \mathrm{~m}$ long, up to $675 \mathrm{~m}$ wide, and covers an area of $0.51 \mathrm{~km}^{2}$. The catchment area of the rock glacier measures $1.59 \mathrm{~km}^{2}$. The steep front of the rock glacier terminates at an elevation of $2164 \mathrm{~m}$; the rooting zone is located at $2668 \mathrm{~m}$. The active layer at the surface is composed of fine- to coarse-grained debris. Grain-size is mostly $<1 \mathrm{~m}$; individual blocks have diameters of up to several metres. The surface displays a pronounced morphology of longitudinal, subordinately of transverse ridges and furrows. The slope of the front is steep $\left(\sim 40^{\circ}\right)$ and is partly covered by vegetation, indicating low activity. At the base of the steep front four springs are developed at which most of the water of the rock glacier is released.

In the rooting zone locally massive ice is exposed at the surface. This ice represents remnants of a small cirque glacier of the Little Ice Age, which covered the rooting zone of the rock glacier. In the upper part younger, active lobes with a steep front are developed. In front of the rock glacier, at a distance of $165 \mathrm{~m}$, a gauging station was installed immediately below the confluence of the small streams released from the four rock glacier springs (Fig. 3a), which belongs to the official spring network of the Hydrographic Service of Tyrol (HZB Nr. 395525). The weather station Ischgl Idalpe is located at a distance of approximately six $\mathrm{km}$ from the rock glacier and provides important data on temperature and precipitation.

\section{Innere Ölgrube (OEG)}

The active rock glacier Innere Ölgrube is located in a small, west-facing tributary valley of the Kauner Valley in the western Ötztal Alps. Bedrock of the catchment area consists of orthogneiss, paragneiss, and mica schists of the ÖtztalStubai Metamorphic Complex (Hoinkes and Thöni 1993). The rock glacier is composed of two tongue-shaped lobes. The northern, larger lobe is composed of orthogneiss debris, the smaller southern lobe of paragneiss and mica schists.

The rock glacier is $896 \mathrm{~m}$ long, up to $334 \mathrm{~m}$ wide covering an area of $0.24 \mathrm{~km}^{2}$. The active front is up to $70 \mathrm{~m}$ high with a steep gradient of $40^{\circ}-45^{\circ}$. The base of the steep front is located at an elevation of $2394 \mathrm{~m}$, the rooting zone is at an elevation of $2727 \mathrm{~m}$. The rock glacier has a distinct surface morphology of transverse and longitudinal furrows and ridges. On the southern lobe three small ponds (most probably thermokarst lakes) are developed in the rooting zone. The catchment of the rock glacier covers an area of $1.83 \mathrm{~km}^{2}$, including two small cirque glaciers with an area of $~ 0.16 \mathrm{~km}^{2}$ (Fig. 3b).

The average grain size of the coarse debris layer ranges mostly between 20 and $40 \mathrm{~cm}$ at the surface, individual blocks have diameters up to several metres. At the base of the steep front five springs are developed (details see Berger et al. 2004; Krainer and Mostler 2002, 2006; Krainer et al. 
Table 1 Overview of rock glacier (rg) and rock glacier catchment (catch) characteristics

Tab. 1 Übersicht der Blockgletscher- (rg) und der Blockgletschereinzugsgebiets- (catch) Charakteristika

\begin{tabular}{llllll}
\hline Test site & Rg type & Rg mean elevation [m a.s.l.] & Rg area $\left[\mathrm{km}^{2}\right]$ & Rg length $[\mathrm{m}]$ & Catch area $\left[\mathrm{km}{ }^{2}\right]$ \\
\hline Schöneben (SRG) & Relict & 1816 & 0.11 & 746 & 0.67 \\
Reichenkar (RK) & Active & 2586 & 0.28 & 1641 & 1.17 \\
Äußeres Hochebenkar & Active & 2670 & 0.48 & 1442 & 1.03 \\
(AHK) & & & & \\
Bergli (BER) & Active & 2455 & 0.51 & 1545 & 1.59 \\
Innere Ölgrube (OEG) & Active & 2582 & 0.24 & 896 & 1.83 \\
\hline
\end{tabular}

2007; Hausmann et al. 2012). The rock glacier is active. In the period 2002-2005 flow velocities of up to $2.5 \mathrm{~m} / \mathrm{year}$ were recorded near the front (Krainer and Mostler 2006). The internal structure of the rock glacier was determined by geophysical methods (GPR, seismics, and gravimetry). The rock glacier is composed of an active layer with a thickness of 4-6m, underlain by the permafrost body $(20-30 \mathrm{~m})$. Between the permafrost body and the bedrock an ice-free sediment layer is present, which is $10-15 \mathrm{~m}$ thick. Ice-content in the permafrost body ranges from 40 to $60 \%$ (Hausmann et al. 2012).

For the rock glacier Innere Ölgrube, a weather station that is located at the opposite side of the Kauner valley at Weißsee (TIWAG; distance $\sim 4 \mathrm{~km}$ ) provided data on precipitation.

\section{Data base and methods}

\section{Discharge and precipitation data}

Discharge data for the gauging stations of SRG in Styria and BER and AHK in Tyrol were provided by the hydrographic services of these federal states. For the other two gauging stations at OEG and RK (both in Tyrol), rating curves have been developed based on a wide range of discharge measurements at various water levels, also covering low flow conditions (Brodacz 2019). Available time series of the discharge values are shown in the insets of Fig. 4 and cover three to five years. For SRG, a longer time series does exist (Winkler et al. 2016), but for the present study data starting in December 2011 were used coinciding with the availability of precipitation data. Smaller data gaps are present in the data of RK and OEG, none in that of SRG (insets of Fig. 4). Longer periods of data gaps in the discharge data of AHK and BER during the winter months are related to the difficulty of such measurements in high alpine environments and are discussed in more detail later. All the available discharge data of the five rock glacier springs were used consistently on an hourly time step for the threshold rainfall-runoff event analyses, as this was the highest consistent resolution available for all time series. The recession analysis was done using a daily time step.
This hereby obtained smoothing of the data reduced the influence of slight fluctuations in the data, which would have interrupted individual recession limbs.

Similarly, precipitation data that were made available from a weather station within the catchment for the relict rock glacier SRG and from nearby weather stations for three active rock glaciers were used consistently on an hourly time step. For precipitation data from nearby weather stations an elevation correction for precipitation (7\% per $100 \mathrm{~m}$ ) was applied according to Kuhn et al. (2013).

\section{Recession analysis}

Discharge time series are based on rating curves where a relationship between water levels and individual various discharge values was developed at the gauging stations downstream of each rock glacier spring. Individual discharge measurements were performed for a wide range of flow conditions using the salt dilution method or simply a bucket of known volume for low flow conditions. As there are uncertainties related to low flows and the general difficulty of data acquisition in high alpine areas (e.g. ice and snow cover; avalanche danger, etc.) where the gauging stations of the active rock glacier are located, absolute values have to be interpreted with some caution. Nevertheless, discharge dynamics are recorded appropriately and water level-discharge measurements were done during a wide range of flow conditions and importantly during low flow periods, thereby reducing uncertainties.

To test if active rock glaciers have a relevant base flow during winter, but also during summer drought periods, spring discharge data of four active rock glacier springs in the Austrian Alps were analyzed and compared to the discharge of a spring at a relict rock glacier. Here we use the term "base flow" for runoff during extended periods of very little to no recharge and consequently a steady decline in discharge based on the drainage of a linear storage. This may be either during drought periods or more consistently during winter periods when precipitation falls as snow and no snow and/or ice melt occurs. Especially for active rock glaciers, care has to be taken during summer drought periods, if within the catchment of the rock glacier spring cirque glaciers are present (e.g. OEG) or potential permafrost ice 
Fig. 4 Master recession curve analysis (semi-log plots) of the five analyzed rock glaciers. a Schöneben (SRG), Reichenkar (RK) and Innere Ölgrube (OEG) and b Äußeres Hochebenkar (AHK) and Bergli (BER) with recession coefficients of the individual flow components in $\mathbf{a}$ for OEG and $\mathbf{b}$ for BER. Insets show the data base of the recession analyses based on discharge time series over a period of three to five years. Note the data gaps during winter recession (modified after Wagner et al. 2019)

Abb. 4 Analyse des Auslaufverhaltens (semi-logarithmische Darstellung) der fünf analysierten Blockgletscher. a Schöneben (SRG), Reichenkar (RK) and Innere Ölgrune (OEG) und b Äußeres Hochebenkar (AHK) and Bergli (BER) mit den Auslaufkoeffizienten der einzelnen Abflusskomponenten in a für $\mathrm{OEG}$ und $\mathbf{b}$ für BER. Insets zeigen die Datengrundlage der Analyse basierend auf Abflusszeitreihen über eine Periode von drei bis fünf Jahren. Datenlücken während des Auslaufens im Winter beachten (modifiziert nach Wagner et al. 2019)

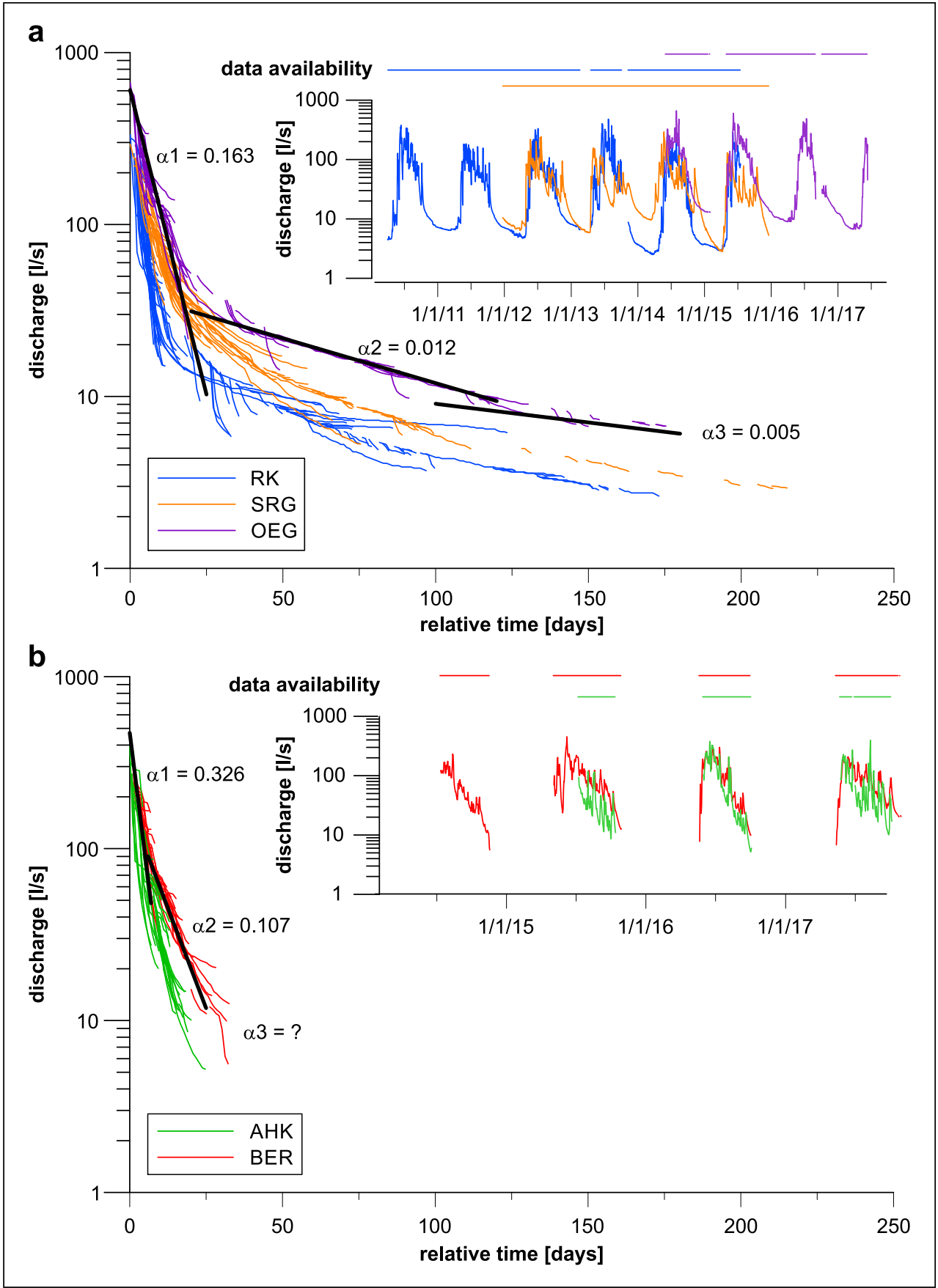

melt is to be expected. These melt waters will not allow observing base flow during these periods in summer. However, during winter periods when generally no ice or snow melt is to be expected, base flow can clearly be observed. Exceptions to this due to mid-winter snowpack loss are reported by e.g. Meeks et al. (2017). However, these are likely to be of subordinate importance here, as catchment elevations are relatively high and winter temperatures well below $0{ }^{\circ} \mathrm{C}$.
Recession analysis is used to identify individual flow components and/or aquifer components and particularly quantify base flow by using a linear storage model approach (Maillet 1905; Kresic and Stevanovic 2010):

$\mathrm{Q}(\mathrm{t})=\mathrm{Q}_{0} \mathrm{e}^{-\alpha \mathrm{t}}$

in which $\mathrm{Q}(\mathrm{t})$ is discharge at time $\mathrm{t}, \mathrm{Q}_{0}$ is discharge at the beginning of the recession and $\alpha$ is the recession coefficient. This analysis allows a comparison of base flow reces- 
Table 2 Overview of recession analyses of all rock glacier springs. Time series/hydrographs are displayed as insets in Fig. 4; $\mathrm{Q}_{\text {min }}$ and $\mathrm{Q}_{\mathrm{max}}$ values are based on hourly time series; remaining values on daily time steps. $\alpha 1, \alpha 2$, and $\alpha 3$... calculated with the MRCTools v3.0 of Posavec et al. (2017); numbers in italic ... average $\alpha$-values of individual flow components of the winter recessions of each analyzed year; V 3 ... stored water volume of the base flow component related to $\alpha 3$ of the single event analysis; b ... estimated thickness with assumed porosity of 0.2 . No volume and consequently thickness were computed if $\alpha 3$ recession coefficients could not be estimated

Tab. 2 Übersicht über die Analysen der Auslaufverhalten der Blockgletscherquellen. Zeitreihen/Hydrographen sind in „Insets“ von Abb. 4 dargestellt; $Q_{\min }$ und $Q_{\max }$ Werte beruhen auf Stundenwerte der Schüttungszeitreihen; restliche Werte auf Tagesbasis. $\alpha 1$, $\alpha 2$ und $\alpha 3$... berechnet mittels MRCTools v3.0 von Posavec et al. (2017); Zahlen in Kursivschrift ... mittlere $\alpha$-Werte der einzelnen Winterauslaufverhalten jedes Jahres der analysierten Daten; V3 ... gespeichertes Wasservolumen der Basisabflusskomponente bezogen auf $\alpha 3$ der Einzelereignisanalysen; b ... Mächtigkeit mit angenommener Porosität von 0.2. Kein Volumen und folglich auch keine Mächtigkeit wurden berechnet, wenn $\alpha 3$ Auslaufkoeffizienten nicht abgeschätzt werden konnten

\begin{tabular}{|c|c|c|c|c|c|}
\hline Rock glacier & Äußeres Hochebenkar (AHK) & Reichenkar (RK) & Innere Ölgrube (OEG) & Bergli (BER) & Schöneben (SRG) \\
\hline Time period & $2015-2017$ & $2010-2015$ & 2014-2017 & $2014-2017$ & $2012-2015$ \\
\hline $\mathrm{Q}_{\min }[1 / \mathrm{s}]$ & 5.1 & 1.9 & 6.5 & 5.0 & 2.6 \\
\hline $\mathrm{Q}_{\max }[1 / \mathrm{s}]$ & 665 & 511.0 & 718 & 522.9 & 335.8 \\
\hline $\mathrm{Q}_{\max } / \mathrm{Q}_{\min }[-]$ & 130.4 & 268.9 & 110.5 & 104.6 & 129.2 \\
\hline \multirow[t]{2}{*}{$\alpha 1\left[\mathrm{~d}^{-1}\right]$} & 0.504 & 0.227 & 0.163 & 0.326 & 0.155 \\
\hline & - & 0.179 & 0.044 & - & 0.075 \\
\hline \multirow[t]{2}{*}{$\alpha 2\left[\mathrm{~d}^{-1}\right]$} & 0.126 & 0.013 & 0.012 & 0.107 & 0.016 \\
\hline & - & 0.013 & 0.012 & - & 0.014 \\
\hline \multirow[t]{2}{*}{$\alpha 3\left[\mathrm{~d}^{-1}\right]$} & $?$ & 0.004 & 0.005 & $?$ & 0.007 \\
\hline & - & 0.003 & 0.004 & - & 0.005 \\
\hline $\mathrm{V} 3_{\min }\left[\mathrm{m}^{3}\right]$ & - & $9.93 E+04$ & $2.24 \mathrm{E}+05$ & - & $9.67 E+04$ \\
\hline $\mathrm{V} 3_{\max }\left[\mathrm{m}^{3}\right]$ & - & $3.63 E+05$ & $5.34 \mathrm{E}+05$ & - & $5.15 E+05$ \\
\hline $\mathrm{B}_{\min }[\mathrm{m}]$ & - & 1.8 & 4.7 & - & 4.5 \\
\hline $\mathrm{B}_{\max }[\mathrm{m}]$ & - & 6.6 & 11.2 & - & 23.9 \\
\hline
\end{tabular}

sion (long-term $\alpha$-values) of individual rock glaciers to each other and to data from a relict rock glacier. Single recession events were analyzed as well as "Master Recession Curves (MRC)" were calculated applying the MRCTools v3.0 of Posavec et al. (2017). Recession coefficients of these MRCs are analyzed and compared to average recession coefficients from single event analyses (winter recessions). When plotting discharge data over time in a semi-logarithmic plot, a straight-line can be fitted to sections of a recession; the lower the slope of this straight line, the slower the recession (here given in units of $\mathrm{day}^{-1}$ ). Various complexities of recession curve analysis exist (e.g. Tallaksen 1995; Lamb and Beven 1997; Hergarten and Birk 2007; Roques et al. 2017; Carlotto and Chaffe 2019). However, the intention here is to provide evidence of a base flow component of active rock glaciers comparable to that of a relict rock glacier and an extensive discussion of recession curve analyses is beyond the scope of this paper (cf. Winkler et al. 2016).

The recession curve separation approach chosen here is based on interpreting different recession coefficients/ sections in terms of different aquifer components (Baedke and Krothe 2001). More complex approaches exist, as for example discussed in Winkler et al. (2016) for SRG using alternative power-law relationships (Hergarten and Birk 2007). The findings of Baedke and Krothe (2001) about the interpretation of multiple linear stores is discussed further by Sahuquillo and Gomez-Hernandez (2003) and Baedke and Krothe (2003). In any case, this is a standard procedure that can be done using discharge data of different springs and direct comparison is readily possible. Importantly, data of different springs are compared in a consistent manner and similarities (or dissimilarities) were demonstrated.

Based on the idea of a linear storage the water volume stored in the aquifer above spring level (V) can be calculated by the discharge at the time of the beginning of the recession related to the recession coefficient (Eq. 2).

$\mathrm{V}(\mathrm{t})=\frac{Q(t)}{\alpha}$

By dividing the stored water volume of the base flow component with the areal extent of the rock glacier multiplied with an assumed porosity of about 0.2 (e.g. Winkler et al. 2016) the mean thickness of the unfrozen basal sediment layer can be estimated. This yields an upper-bound estimate for the thickness, as other parts within the rock glacier spring catchment might potentially contribute to groundwater storage (e.g. talus as discussed in Winkler et al. (2016) and Pauritsch et al. (2017)). However, the groundwater flux through the rock glacier is assumed to be similar or less than the flux through the upgradient sediments (e.g. talus deposits) and therefore the relevant ratecontrolling hydrogeomorphic unit of the watershed as all groundwater fluxes from other upgradient parts of the watershed must eventually flow through the rock glacier. The 
assumed porosity of 0.2 for all rock glaciers is owing to the fact, that the actual values are not known for the individual rock glaciers but are acceptable literature values for these type of sediments (e.g. Winkler et al. 2016).

\section{Threshold analysis}

In a second step, spring stormflow is compared to precipitation events. A certain threshold in precipitation might be needed to see a distinct response (increase) on discharge at the spring (Harrington et al. 2018).

The constant-discharge method was used to quantify the event water rate after precipitation events (McCuen 2005). The event water is computed by the volume of water that is defined as the entire discharge above a horizontal line connecting the lowest pre-storm discharge to the point where the same discharge is intersected on the recession limb of the hydrograph (cf. Harrington 2017; Harrington et al. 2018). This simplification is necessary as natural tracer data were not available at all rock glacier springs to supplement discharge data to separate event water from older, longer stored water (cf. Winkler et al. 2016). This necessary simplification is likely to result in an overestimation of event water (compare to Winkler et al. 2016). However, it allows comparing the different spring catchments to each other in a consistent manner. In addition, a systematic overestimation of event water due to the simple separation technique would not change a potential threshold value nor a possible linear relationship between precipitation amount and event water amount, but would result in a different (less steep) gradient. Weather stations in or near the rock glacier catchments were used to quantify the precipitation input. Only rainfall and no snow events were analyzed. Data were normalized to the spring catchment area and given in millimetres.

The results of this approach might indicate i) if there is a certain threshold that needs to be met so that the aquifer response to precipitation becomes relevant, and ii) if the aquifer response to precipitation events is comparable between various rock glaciers. The former information is used based on a process understanding that was developed in hill slope hydrology (Tromp-van Meerveld and Mc Donnell 2006), to derive a certain threshold related to a filling of the aquifer to become active. The latter focuses on the fast flow component. Harrington et al. (2018) showed that a linear relationship between precipitation and discharge volume might develop. A similar slope of the linear relationship between precipitation event volume and event water volume for different rock glaciers might suggest that about the same percentage of infiltrating water is released over time during similar events.

\section{Results}

The general discharge dynamics can be described by the minimum and maximum values over a year or a longer time period. Discharge data (hourly resolution) of all active rock glacier springs show highest discharge values of more than 5001/s with a maximum of $7181 / \mathrm{s}$ at OEG (Table 2). These values are approximately twice of the maximum discharge at the relict rock glacier SRG (Table 2), which has about half of the catchment size compared to the active rock glaciers (Table 1). The lowest discharge values of the available time series are a few liters per second and are similar for active and relict rock glaciers. The ratio of maximum versus minimum discharge is for SRG and OEG above 100, and for RK 270. Discharge ratios of BER and AHK are similar to SRG and OEG (above 100). However, during winter no discharge data were recorded. These two gauging stations are located at a distance to the actual springs and during winter periods freezing of water along the flow path between springs and gauging stations does not allow to fully observe winter base flow.

\section{Recession analysis}

Recession coefficients are computed on one hand by using a master recession curve (Fig. 4; MRC; Posavec et al. 2017) and on the other hand by using single event analysis (summarized in Fig. 5). Besides gaps in discharge data during winter periods for AHK and BER (Fig. 4b), some data gaps occurred at OEG which are shown in the inset in Fig. 4a. These did not hamper the recession analysis. Fig. 4 shows the master recession curves of all studied rock glaciers. Generally, the recession analyses clearly indicate three $\alpha$-values for OEG, RK and SRG (Figs. 4 and 5; and Table 2) representing at least two flow components for each of these active rock glaciers (cf. Winkler et al. 2016). A fast flow component and a relevant base flow component can be identified, whereas the intermediate $\alpha$-values are interpreted to be a combination of fast and slow flow components (similar to interpretations of conduit and diffuse/matrix flow in karst systems; Baedke and Krothe 2001). MRCs for AHK and BER are limited to summer periods (no winter data) and although various straight line segments could be separated, they represent the fast and to some extend a transition to intermediate flow conditions (compare Fig. 4a,b). Fig. 5 shows box-whisker plots of the three $\alpha$-values for RK, OEG, and SRG using single event analysis. For the rock glacier springs of AHK and BER, where no discharge was recorded during winter, it was not possible to quantify base/low flow. Therefore, single event recession analysis-in particular for $\alpha 3$-is limited at these rock glacier springs and thus is not included in Fig. 5. The recession pattern of the other active rock glaciers (OEG and RK) 


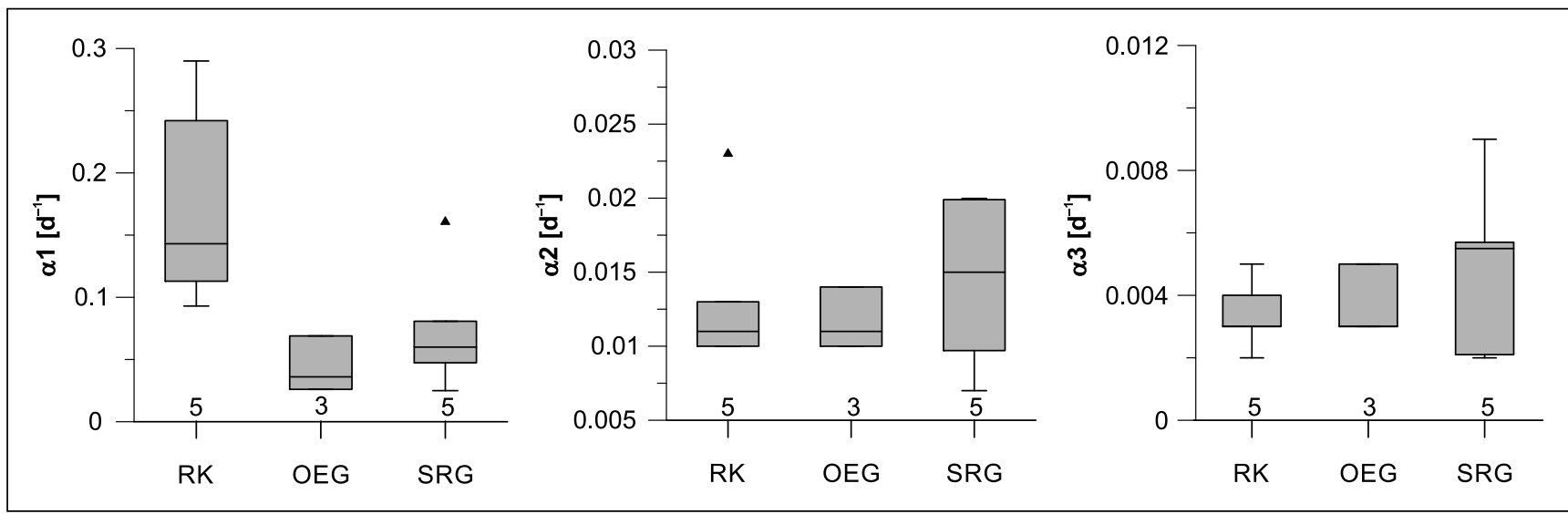

Fig. 5 Box-whisker plots of the three recession coefficients ( $\alpha$-values) of the rock glacier springs at Reichenkar (RK), Innere Ölgrube (OEG), and Schöneben (SRG) based on single event analysis. Numbers above the x-axis are the samples and black triangles are outliers (modified after Brodacz 2019)

Abb. 5 Box-Whisker Darstellung der drei Auslaufkoeffizienten ( $\alpha$-Werte) der Blockgletscherquellen Reichenkar (RK), Innere Ölgrube (OEG) und Schöneben (SRG) basierend auf Analysen von Einzelevents. Zahlen über der x-Achse sind die Anzahl der analysierten Ereignisse und schwarze Dreiecke stellen Ausreißer dar (modifiziert nach Brodacz 2019)

is comparable (same order of magnitudes) to that of the relict rock glacier (SRG) as can be seen by the recession coefficients in Table 2 and Fig. 5.

As a consequence, the analyses of the recession coefficients and particularly $\alpha 3$-values allow the quantification of the stored water volume related to the base flow (Eq. 2). Table 2 lists an upper bound estimate of the thicknesses of the saturated unfrozen basal sediment layers. The thickness of the "base flow layer" of RK and OEG ranges from almost 2 and $5 \mathrm{~m}$ up to nearly $7 \mathrm{~m}$ and more than $11 \mathrm{~m}$, respectively. The base layer thickness at SRG might be more than $20 \mathrm{~m}$; when considering a potentially slightly larger extend of the rock glacier (underneath current talus deposits) of $\sim 0.17 \mathrm{~km}^{2}$ (instead of $0.11 \mathrm{~km}^{2}$ ), a somewhat thinner base layer would be estimated as discussed in Winkler et al. (2016).

\section{Threshold analysis}

In addition, the topography of the aquifer base or the surface between two aquifer layers with different hydraulic properties is of relevance for the drainage pattern of aquifers and its layers. In particular, topographic depressions in the bedrock might represent groundwater storages which have to be filled and thus might delay or even hamper the increase of discharge after rain events following the fill-spill (-drain) hypotheses (Tromp-van Meerveld and Mc Donnell 2006; Tromp-van Meerveld et al. 2007). Therefore, spring discharge data were analyzed at springs of AHK, BER, OEG, and SRG where precipitation data were available from weather stations nearby (Fig. 6).

The analysis of precipitation to normalized event water volume shows some similarities between the investigated rock glaciers (Fig. 6). A precipitation amount of about $18 \mathrm{~mm}$ (normalized to the spring catchment area) is needed for a noticeable response of spring discharge of the active rock glaciers (AHK, BER, OEG) on rain events, followed by some linear correlation between precipitation and event water above this threshold (Fig. 6). A further increase of event water ("volume") correlates with the increase of precipitation amount with a slope of roughly 0.5 where the lowest slope of 0.43 is observed at BER. AHK and OEG show very similar slopes with 0.58 and 0.59 , respectively. The data of the relict rock glacier SRG show a more scattered behavior, but can be delimited by slopes of 0.59 , similar to the slopes observed for the active rock glaciers AHK and OEG. Contrary to the active ones, the relict rock glacier does not show an actual threshold value. Instead, a more scattered relation between precipitation and event water is observed and temporarily up to about $60 \mathrm{~mm}$ of precipitation is needed for a noticeable increase in the volume of event water.

\section{Discussion}

The discharge pattern of the four investigated springs draining active rock glacier catchments is characterized by a high variability with a range of $\mathrm{Q}_{\max }$ and $\mathrm{Q}_{\min }$ (maximum and minimum measured discharge over observation period, respectively) from several hundreds of $1 / \mathrm{s}$ to about a few $1 / \mathrm{s}$ yielding discharge ratios $\left(\mathrm{Q}_{\max } / \mathrm{Q}_{\min }\right)$ of more than 100. A similar variability was already observed at several rock glacier springs (relict, inactive, and active) where discharge was measured (Untersweg and Schwendt 
Fig. 6 Threshold analyses of four rock glaciers; the relict SRG and the three active ones: AHK, BER, and OEG. RK is not shown here, because no representative weather station is located in the area and consequently precipitation input could not be quantified (modified after Brodacz 2019). Red lines fitted to data beyond the interpreted precipitation threshold for AHK, BER and OEG; for SRG the red lines represent the envelops. Note the different extents of the axes of the individual plots

Abb. 6 Schwellenwertanalyse von vier Blockgletschern; dem reliktischen SRG und den drei aktiven: AHK, BER und OEG. RK ist hier nicht gezeigt, weil keine repräsentative Wetterstation in dieser Gegend und dadurch kein Niederschlagseintrag für dieses Gebiet quantifiziert werden konnte (modifiziert nach Brodacz 2019). Rote Trendlinien beziehen sich nur auf Daten nach dem interpretierten Schwellenwert für AHK, BER und OEG; für SRG die roten Linien stellen die Einhüllenden dar. Man beachte die unterschiedliche Achsenskalierung der einzelnen Grafiken
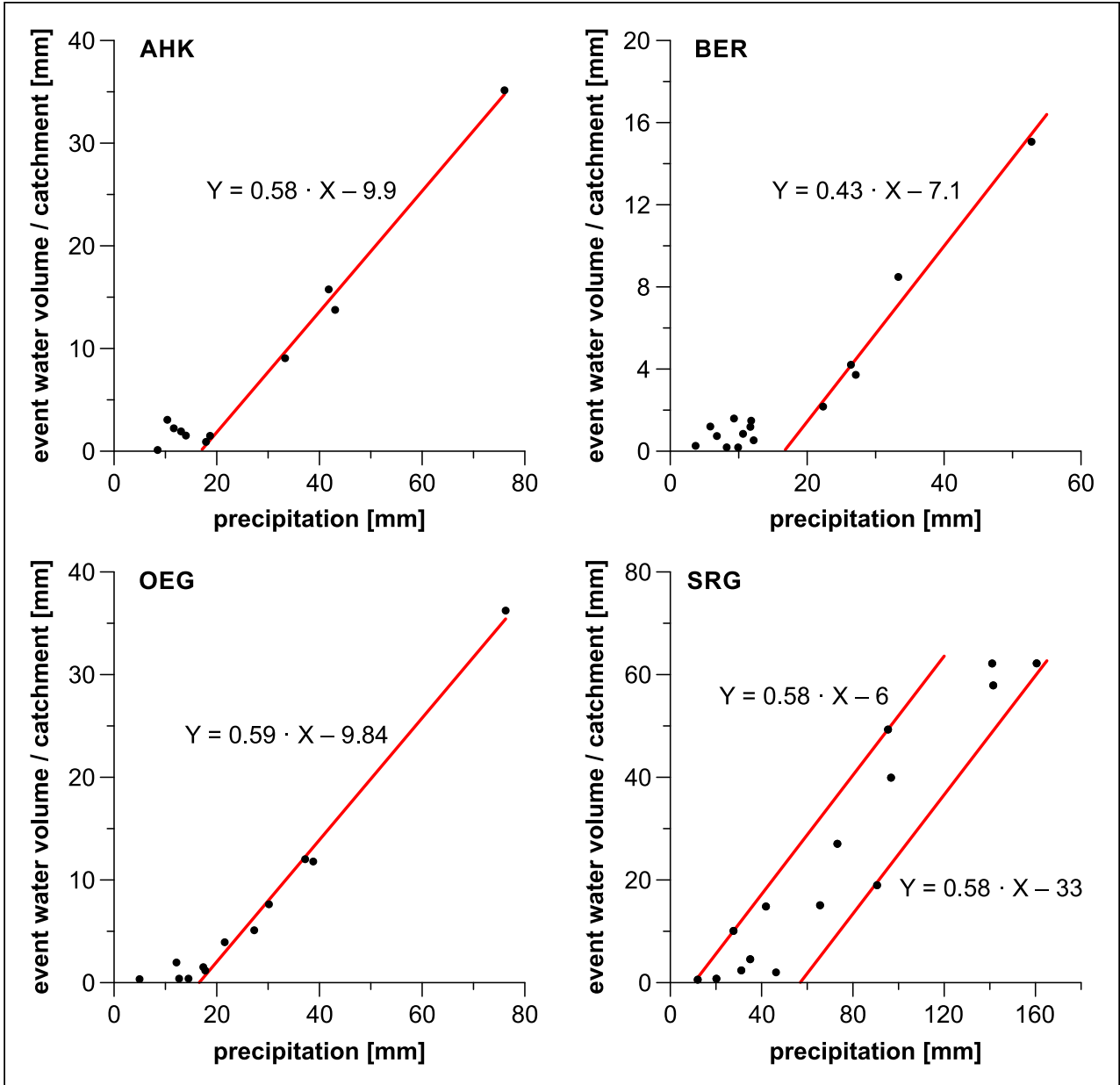

1995, 1996; Krainer and Mostler 2002; Krainer et al. 2007; Winkler et al. 2016; Harrington et al. 2018).

\section{Recession analysis}

The recession analyses of the four active rock glaciers indicate at least a two-phase recession containing a slow and a fast flow component, similar to observations in karst aquifers (e.g. Baedke and Krothe 2001). The intermediate section (related to $\alpha 2$-values) is interpreted to be a combination of fast and slow flow components (e.g. Baedke and Krothe 2001). The separation into more than one flow component for each of these four active rock glaciers is in accordance with earlier studies based on isotope data (Krainer and Mostler 2002; Krainer et al. 2007). Fast flow components observed at the active rock glaciers represent the early recession part and the recession coefficients ( $\alpha 1$-values) are similar or even higher than those of the relict rock glacier SRG and an inactive rock glacier at Helen Creek (Winkler et al. 2016; Harrington et al. 2018). The higher early recession coefficients at active rock glaciers compared to that of the relict rock glacier (SRG) may be explained by the fact that lateral flow within the active layer (on top of the permafrost body) is taking place and thus results in a faster drainage. At the relict rock glacier SRG, infiltrating water flows through the rather thick unsaturated zone before lateral flow on top of the saturated zone may occur (Winkler et al. 2018; Wagner et al. 2019).

The slow flow component observed at the active rock glaciers RK and OEG is similar to that of the relict rock glacier and that at Helen Creek (inactive rock glacier, Harrington et al. 2018). This flow component can be related to the base flow when little to no recharge occurs for longer time periods. At the relict rock glacier SRG, the base flow component is related to a fine-grained base layer (Winkler et al. 2016; Pauritsch et al. 2015, 2017). When considering the base flow component of the active rock glaciers using $\alpha 3$-values, the related upper bound volume of groundwater within the rock glacier debris accumulation can be estimated. By distributing this volume evenly across the area of the base of the rock glacier, an average thickness of the saturated zone within the rock glaciers was estimated to be in the order of $10 \mathrm{~m}$ (Table 2). Although this is an upper bound estimate due to potentially addi- 
tional debris (e.g. talus deposits) acting as groundwater storage, the similarity and comparability of the base flow component of all active, inactive, and relict rock glaciers suggest a fine-grained base layer as a possibility of storing groundwater within the studied rock glacier catchments that is very likely situated within the rock glacier debris. Such an unfrozen base layer is reported by other studies applying geophysical investigations at RK and OEG resulting in the presence of a $\sim 10 \mathrm{~m}$ thick unfrozen base layer (Hausmann et al. 2007, 2012) and drillings at the active rock glacier Lazaun (Krainer et al. 2015). This unfrozen base layer at active and inactive rock glaciers might provide some discharge during winter periods or other time periods with little to no recharge. A relevant base flow component was also reported by Williams et al. (2006) for an active rock glacier in the Rocky Mountains Front Range. They attributed parts of the base flow to permafrost ground ice melt based on isotope data. At the herein investigated active rock glaciers, base flow during winter periods is very likely not related to permafrost ground ice melt as during winter times at temperatures well below $0^{\circ} \mathrm{C}$ no melting should occur, but more likely seems to be related to a relevant groundwater component. This was already suggested for RK and OEG by isotopic data in Krainer et al. (2007), by electrical conductivity data for OEG in Brodacz (2019) and using a combination of both for BER in Wagner et al. (2019). Additional indirect data for a base flow during winter can be postulated from observations at the active rock glacier Krummgampen (e.g. Thies et al. 2013), a few kilometres southwest of the OEG in the Kauner valley. Wagner et al. (2019) present continuous water temperature data of a spring at the front of the Krummgampen rock glacier over the winter period 2017-2018 indicating a continuous water flow during winter (as temperatures do not drop below zero).

\section{Threshold analysis}

Besides the (unfrozen) base layer within the rock glacier body, also the actual bedrock morphology on which a particular rock glacier is situated (or moving along) may be important for the discharge characteristics of rock glacier springs as suggested by Harrington et al. (2018). When analyzing the relation between precipitation amount and event water outflow at a rock glacier spring, a certain threshold might be observed which is necessary to initiate a noticeable discharge increase. Based on process understanding from hillslope hydrology, fill-spill or fill-spilldrain processes (Tromp-van Meerveld and Mc Donnell 2006; Tromp-van Meerveld et al. 2007) might also be important in rock glacier hydrogeology. Harrington et al. (2018) showed a clear threshold behavior for an inactive rock glacier in the Canadian Rockies. There are also thresholds observable here for the active rock glaciers in the Austrian Alps (Fig. 6), although some weak discharge reactions (low event flow volumes) below the threshold are observed. Nevertheless, some $18 \mathrm{~mm}$ of rainfall appear to be necessary to trigger noticeable discharge increases at rock glacier springs. With a porosity of 0.2 and considering only the rock glacier area, a rainfall event of $18 \mathrm{~mm}$ within the total catchment area would account for a saturated thickness of $0.38,0.68$ and $0.55 \mathrm{~m}$ for RK, OEG and SRG, respectively. This is much less than the estimated minimum layer thickness of the (unfrozen) base layer for these rock glaciers (Table 2). A likely scenario is that variable topography with occasional depression or pool structures of the bedrock and likely also the permafrost table (base of the active layer) in active rock glaciers needs to be "filled" first before runoff at the spring can be initiated. Over time, drainage of these depressions is however possible in a diffuse way through fractures (in permafrost ice and bedrock) or weathering zones (in bedrock). Nevertheless, topography alone seems to explain only a small part of the base flow and the fine-grained unfrozen base layer between the bedrock and the permafrost body is suggested to provide the major contribution to base flow for the analyzed rock glaciers (cf. Winkler et al. 2016; Pauritsch et al. 2017).

A question that remains to be answered is why the relict SRG does not show such a clear threshold but a more scattered behavior. A possible difference is lateral flow initiated in the active layer within the active rock glacier, but infiltration of water down to the variably saturated base layer within the relict rock glacier. It is unclear if this is a general characteristic of relict rock glaciers, as data of only a single relict rock glacier (SRG) are available for analysis. It remains to be shown that the discharge pattern of the relict rock glacier Schöneben is representative for relict rock glaciers in general.

It is, however, of interest, that a linear relationship between the amount of precipitation and released event water appears to exist. Some 50-60\% of precipitation (when subtracting the threshold amount) flows rather quickly through the rock glacier body to generate an increase in discharge (slope of $\sim 0.5-0.6$ in Fig. 6). Such an event water share of the discharge was reported using natural tracers such as electrical conductivity or isotope data for the OEG (Heigert 2019). In addition, a similar response of discharge on precipitation amount is observed at the inactive rock glacier Helen Creek (Harrington et al. 2018).

For the relict SRG however, computed event water contributions using natural tracers such as electrical conductivity or isotope data are reported to be in the order of $20 \%$ (e.g. Winkler et al. 2016). Considering such a more sophisticated event water separation (e.g. based on EC or isotope data, c.f. Winkler et al. 2016), these values might be more consistent as the simplification for event water 
separation used here likely overestimates event water. SRG shows a scattered relationship between amount of precipitation and event water. This is suggested to be related to the fill-level of the bedrock depressions in addition to the saturation of the fine-grained base layer before the individual precipitation event (Pauritsch et al. 2017).

\section{General implications}

Based on the analyses presented above, we assume that active as well as relict rock glaciers may have a considerable base flow component that is related to a relatively finegrained unfrozen base layer, which may provide groundwater storage and buffer capabilities affecting discharge patterns of alpine headwaters. This is of high relevance for water management issues in particular considering that e.g. in the Austrian Alps a total of 5769 rock glaciers are known (Wagner et al. in press). For the entire European Alps the estimated numbers are much higher (Jones et al. 2019). Moreover, the observed groundwater buffer and storage (retention) capacities of these landforms may even become more important for ecosystem services as climate change progresses and meteorological drought as well as storm events might increase (e.g. Gobiet et al. 2014). Further, the permafrost ground ice body within the active (or intact in general) rock glaciers might shrink and finally disappear in the future (e.g. Jones et al. 2019), thereby potentially increasing the groundwater storage capacity of rock glaciers (Rogger et al. 2017). The impact and importance of rock glaciers and their groundwater storage capacities on alpine hydro(geo)logy and in particular on second or third order rivers was shown by recent studies (e.g. Wagner et al. 2016; Rogger et al. 2017; Schaffer et al. 2019). But it has to be noted, that groundwater storage and buffer capabilities of rock glaciers are limited (at least for the ones analyzed herein), as the main groundwater storage seems to be related to the (unfrozen) fine-grained base layer, which has a thickness in the order of $\sim 10 \mathrm{~m}$. This means that intense storm events will be transferred quickly through a rock glacier body if the base layer is already saturated from previous events and lateral flow through the coarser upper layer(s) is dominant. The hydrological relevance of rock glaciers to runoff in alpine catchments (and permafrost within the cryosphere in general) will likely gain in importance as climate change progresses. Besides potential melt of permafrost ice within these landforms and related runoff contributions (Jones et al. 2018, 2019), the shallow groundwater component discussed herein is another hydrological function that needs consideration. Further long-term monitoring at these and other rock glacier sites is necessary for a better understanding of the rock glaciers contributions to discharge dynamics of alpine headwaters. However, rock glaciers are only one of several sedimentary aquifer types in alpine headwaters and their integration in large-scale hydrology is still challenging. Research on these topics should be intensified in the future (Cochand et al. 2019; Hayashi 2019).

\section{Conclusion}

The results of this study confirm that the investigated relict and active rock glaciers contain a fine-grained unfrozen basal sediment layer, which is interpreted here as an aquifer type with potentially high storage capacity. For the first time, data of base flow components are presented for active rock glaciers providing some runoff during longer periods with very little to no recharge (winter periods). The data also allow a rough estimate of the thickness of this basal sediment layer to be in the order of about $10 \mathrm{~m}$, which is consistent with geophysical data. This is important as for example in the European Alps, several thousands of rock glaciers are known and thus provide in total a large groundwater storage capacity. This brings awareness to the fact that rock glaciers in general may affect notably the runoff pattern of alpine headwaters and thus should be taken into account for ecological and water management issues. Particularly in the course of climate change, their groundwater storage, and buffer capabilities (retention) may be important during meteorological droughts and storm events. Additionally, a better understanding of a potential change in timing and quantity of infiltration/recharge processes is necessary to estimate changes in future runoff characteristics of these shallow groundwater bodies. Though the knowledge about the runoff dynamics of rock glaciers is constantly growing, the integration in large-scale hydrological studies is still challenging. In particular it is important to fill the gap between field-based knowledge of local drainage behavior of landforms such as rock glaciers and its impact on higher order rivers with respect to climate change.

Acknowledgements Digital elevation models and topographic maps were provided by the GIS Service of the Federal Governments of Styria, Salzburg, Carinthia, Vorarlberg, and Tyrol. Provision of weather station data by the ZAMG (Obergurgl, Ischgl Idalpe) and the TIWAG (Weißsee) are kindly appreciated by the authors. The very constructive comments and suggestions of three anonymous reviewers and Nico Goldscheider are highly appreciated.

Funding This work was co-funded by the Austrian Federal Ministry of Sustainability and Tourism and the Federal States of Styria, Salzburg, Carinthia, Vorarlberg, and Tyrol (BBK-Nr. 101093).

Funding Open access funding provided by University of Graz.

Open Access This article is licensed under a Creative Commons Attribution 4.0 International License, which permits use, sharing, adaptation, distribution and reproduction in any medium or format, as long as you give appropriate credit to the original author(s) and the source, provide a link to the Creative Commons licence, and indicate if changes 
were made. The images or other third party material in this article are included in the article's Creative Commons licence, unless indicated otherwise in a credit line to the material. If material is not included in the article's Creative Commons licence and your intended use is not permitted by statutory regulation or exceeds the permitted use, you will need to obtain permission directly from the copyright holder. To view a copy of this licence, visit http://creativecommons.org/licenses/by/4. $0 /$.

\section{References}

Baedke, S.J., Krothe, N.C.: Derivation of effective hydraulic parameters of a karst aquifer from discharge hydrograph analysis. Water Resour. Res. 37(1), 13-19 (2001)

Baedke, S.J., Krothe, N.C.: Reply to comment by A. Sahuquillo and J. Jaime Gomez-Hernandez on "Derivation of effective hydraulic parameters of a karst aquifer from discharge hydrograph analysis. Water Resour. Res. 39(6), 1153 (2003)

Barsch, D.: Rockglaciers: Indicators for the Present and Former Geoecology in High Mountain Environments. Springer Series in Physical Environment, vol. 16. Springer, Berlin (1996)

Berger, J., Krainer, K., Mostler, W.: Dynamics of an active rock glacier (Ötztal Alps, Austria). Quat. Res. 62, 233-242 (2004)

Brodazc, A.: Speicherverhalten und Entwässerungsdynamik von Blockgletschern - Vergleichende Untersuchungen zwischen intakten und reliktischen Blockgletschern. Unpublished Master Thesis, University of Graz. (2019)

Burger, K.C., Degenhardt, J.J., Giardino, J.R.: Engineering geomorphology of rock glaciers. Geomorphology 31, 93-132 (1999)

Carlotto, T., Chaffe, P.L.B.: Master recession curve parameterization tool (MRCPtool): different approaches to recession curve analysis. Comput Geosci 132, 1-8 (2019)

Cochand, M., Christe, P., Ornstein, P., Hunkeler, D.: Groundwater storage in high alpine catchments and its contribution to streamflow. Water Resour. Res. 55(4), 2613-2630 (2019)

Geiger, S.T., Daniels, J.M., Miller, S.N., Nicholas, J.W.: Influence of rock glaciers on stream hydrology in the La Sal Mountains, Utah. Arct. Antarct. Alp. Res. 46(3), 645-658 (2014)

Giardino, J.R., Vitek, J.D., DeMorett, J.L.: A model of water movement in rock glaciers and associated water characteristics. In: Dixon, J.C., Abrahams, A.D. (eds.) Periglacial Geomorphology, pp. 159-184. Wiley, Chichester (1992)

Gobiet, A., Kotlarski, S., Beniston, M., Heinrich, G., Rajczak, J., Stoffel, M.: 21st century climate change in the European Alps-a review. Sci. Total Environ. 493, 1138-1151 (2014)

Grêt-Regamey, A., Brunner, S.H., Kienast, F.: Mountain ecosystem services: who cares? Mt. Res. Dev. 32(S1), 23-34 (2012)

Harrington, J.S.: The hydrogeology of a rock glacier and its effect on stream temperature. Unpublished master's thesis. University of Calgary, Calgary, Canada (2017)

Harrington, J.S., Hayashi, M., Kurylyk, B.L.: Influence of a rock glacier spring on the stream energy budget and cold-water refuge in an alpine stream. Hydrol. Process. 31, 4719-4733 (2017)

Harrington, J.S., Mozil, A., Hayashi, M., Bentley, L.R.: Groundwater flow and storage processes in an inactive rock glacier. Hydrol. Process. 32, 3070-3088 (2018)

Hausmann, H., Krainer, K., Brückl, E., Mostler, W.: Internal structure and ice content of Reichenkar Rock Glacier (Stubai Alps, Austria) assessed by geophysical investigations. Permafr. Periglac. Process. 18, 351-367 (2007)

Hausmann, H., Krainer, K., Brückl, E., Ullrich, C.: Internal structure, ice content, and dynamics of Olgrube and Kaiserberg rock glaciers (Otztal Alps, Austria) determined from geophysical surveys. Austrian J. Earth Sci. 105, 12-31 (2012)
Hayashi, M.: Alpine hydrogeology: the critical role of groundwater in sourcing the headwaters of the world. Groundwater (2019). https://doi.org/10.1111/gwat.12965

Heigert, K.: Speicherverhalten und Abflussdynamik aktiver Blockgletscher am Beispiel „Ölgrube Süd“, Kaunertal. Beitr. Hydrogeol. 62, 33-51 (2019)

Hergarten, S., Birk, S.: A fractal approach to the recession of spring hydrographs. Geophys. Res. Lett. 34, L11401 (2007)

Hoinkes, G., Thoni, M.: Evolution of the Ötztal-Stubai, Scarl-Campo and Ulten basement units. In: von Raumer, J.F., Neubauer, F. (eds.) Pre-Mesozoic Geology in the Alps, pp. 485-494. Springer, Berlin, Heidelberg (1993)

Huss, M.: Present and future contribution of glacier storage change to runoff from macroscale drainage basins in Europe. Water Resour. Res. 47, W7511 (2011)

Huss, M., Hock, R.: Global-scale hydrological response to future glacier mass loss. Nature Clim. Change 8, 135-140 (2018)

Jones, D.B., Harrison, S., Anderson, K., Selley, H.L., Wood, J.L., Betts, R.A.: The distribution and hydrological significance of rock glaciers in the Nepalese Himalaya. Glob. Planet. Change 160, 123-142 (2018)

Jones, D.B., Harrison, S., Anderson, K., Whalley, W.B.: Rock glaciers and mountain hydrology: a review. Earth Sci. Rev. 193, 66-90 (2019)

Krainer, K.: Der aktive Blockgletscher im Äußeren Hochebenkar. In: Schallhart, N., Erschbamer, B. (eds.) Forschung am Blockgletscher-Methoden und Ergebnisse Series Alpine Forschungsstelle Obergurgl, vol. 4, pp. 55-75. Innsbruck University Press, Innsbruck (2015)

Krainer, K., Mostler, W.: Reichenkar Rock Glacier: a glacier derived debris-ice system in the Western Stubai Alps, Austria. Permafr. Periglac. Process. 11, 267-275 (2000)

Krainer, K., Mostler, W.: Hydrology of active rock glaciers: examples from the Austrian Alps. Arct. Antarct. Alp. Res. 34, 142-149 (2002)

Krainer, K., Mostler, W.: Flow velocities of active rock glaciers in the Austrian Alps. Geogr. Ann. 88A(4), 267-280 (2006)

Krainer, K., Mostler, W., Span, N.: A glacier-derived, ice-cored rock glacier in the western Stubai Alps (Austria): evidence from ice exposures and ground penetrating radar investigation. Z. Gletscherkd. Glazialgeol. 38, 21-34 (2002)

Krainer, K., Mostler, W., Spötl, C.: Discharge from active rock glaciers, Austrian Alps: a stable isotope approach. Austrian J. Earth Sci. 100, 102-112 (2007)

Krainer, K., Bressan, D., Dietre, B., Haas, J.N., Hajdas, I., Lang, K., Mair, V., Nickus, U., Reidl, D., Thies, H., Tonidandel, D.: A 10,300-year-old permafrost core from the active rock glacier Lazaun, southern Ötztal Alps (South Tyrol, northern Italy). Quat. Res. 83(2), 324-335 (2015)

Kresic, N., Stevanovic, Z.: Groundwater Hydrology of Springs: Engineering, Theory, Management, and Sustainability. Elsevier, Butterworth-Heinemann, Amsterdam, p 573 (2010)

Kuhn, M., Dreiseitl, E., Emprechtinger, M.: Temperatur und Niederschlag an der Wetterstation Obergurg1, 1953-2011. In: Koch, E.M., Erschbamer, B. (eds.) Klima, Wetter, Gletscher im Wandel Alpine Forschungsstelle Obergurgl, vol. 3, pp. 11-30. Innsbruck University Press, Innsbruck (2013)

Lamb, R., Beven, K.: Using interactive recession curve analysis to specify a general catchment storage model. Hydrol. Earth Syst. Sci. 1, 101-113 (1997)

Liu, F., Williams, M.W., Caine, N.: Source waters and flow paths in an alpine catchment, Colorado Front Range, United States. Water Resour. Res. 40, W9401 (2004)

Maillet, E.: Essais d'hydraulique souterraine et fluviale. Librairie Scientifique A. Hermann, Paris (1905)

McCuen, R.H.: Hydrologic Analysis and Design, 3rd edn. Pearson Prentice Hall, Upper Saddle River (2005) 
Meeks, J., Moeck, C., Brunner, P., Hunkeler, D.: Infiltration under snow cover: modeling approaches and predictive uncertainty. J. Hydrol. 546, 16-27 (2017)

Neal, E.G., Hood, E., Smikrud, K.: Contribution of glacier runoff to freshwater discharge into the Gulf of Alaska. Geophys. Res. Lett. 37, L6404 (2010)

Nickus, U., Krainer, K., Thies, H., Tolotti, M.: Blockgletscherabflüsse im Äußeren Hochebenkar - Hydrologie, Wasserchemie und Kieselalgen. In: Schallhart, N., Erschbamer, B. (eds.) Forschung am Blockgletscher-Methoden und Ergebnisse Alpine Forschungsstelle Obergurgl, vol. 4, pp. 117-134. Innsbruck University Press, Innsbruck (2015)

Pauritsch, M., Birk, S., Wagner, T., Hergarten, S., Winkler, G.: Analytical approximations of discharge recessions for steeply sloping aquifers in alpine catchments. Water Resour. Res. 51(11), 8729-8740 (2015)

Pauritsch, M., Wagner, T., Winkler, G., Birk, S.: Investigating groundwater flow components in an Alpine relict rock glacier (Austria) using a numerical model. Hydrogeol. J. 25(2), 371-383 (2017)

Pfingstl, S., Kurz, W., Schuster, R., Hauzenberger, C.: Geochronological constraints on the exhumation oft he Austroalpine Seckau Nappe (Eastern Alps). Austrian J. Earth Sci. 108(1), 172-185 (2015)

Posavec, K., Giacopetti, M., Materazzi, M., Birk, S.: Method and Excel VBA algorithm for modeling master recession curve using trigonometry approach. Groundwater 55(6), 891-898 (2017)

Rogger, M., Chirico, G.B., Hausmann, H., Krainer, K., Brückl, E., Stadler, P., Blöschl, G.: Impact of mountain permafrost on flow path and runoff response in a high alpine catchment. Water Resour. Res. 53, 1288-1308 (2017)

Roques, C., Rupp, D.E., Selker, J.S.: Improved streamflow recession parameter estimation with attention to calculation of -dQ/dt. Adv. Water Resour. 108, 29-43 (2017)

Sahuquillo, A., Gomez-Hernandez, J.J.: Comment on "Derivation of effective hydraulic parameters of a karst aquifer from discharge hydrograph analysis" by Baedke, S.J., and Krothe, N.C. Water Resour. Res. 39(6), 1152 (2003)

Schaffer, N., MacDonell, S., Réveillet, M., Yáñez, E., Valois, R.: Rock glaciers as a water resource in a changing climate in the semiarid Chilean Andes. Reg. Environ. Change 19, 1263-1279 (2019)

Shannon, S., Smith, R., Wiltshire, A., Payne, T., Huss, M., Betts, R., Caesar, J., Koutroulis, A., Jones, D., Harrison, S.: Global glacier volume projections under high-end climate change scenarios. Cryosphere 13, 325-350 (2019)

Tallaksen, L.M.: A review of baseflow recession analysis. J. Hydrol. 165, 349-370 (1995)

Thies, H., Nickus, U., Tolotti, M., Tessadri, R., Krainer, K.: Evidence of rock glacier melt impacts on water chemistry and diatoms in high mountain streams. Cold Reg. Sci. Technol. 96, 77-85 (2013)

Tromp-Van Meerveld, H.J., McDonnell, J.J.: Threshold relations in subsurface stormflow: 2 . The fill and spill hypothesis. Water Resour. Res. 42, W2411 (2006)
Tromp-Van Meerveld, H.J., Peters, N.E., McDonnell, J.J.: Effect of bedrock permeability on subsurface stormflow and the water balance of a trenched hillslope at the Panola Mountain Research Watershed, Georgia, USA. Hydrol. Process. 21, 750-769 (2007)

Untersweg, T., Schwendt, A.: Die Quellen der Blockgletscher in den Niederen Tauern. Bericht der wasserwirtschaftlichen Planung Nr. 78. Amt der Steiermärkischen Landesregierung, Graz, p 76 (1995)

Untersweg, T., Schwendt, A.: Blockgletscher und Quellen in den Niederen Tauern. Mitt. Österreichischen Geol. Ges. 87, 47-55 (1996)

Wagner, T., Pauritsch, M., Winkler, G.: Impact of relict rock glaciers on spring and stream flow of alpine watersheds: examples of the Niedere Tauern Range, Eastern Alps (Austria). Austrian J. Earth Sci. 109(1), 84-98 (2016)

Wagner, T., Kainz, S., Wedenig, M., Pleschberger, R., Krainer, K., Kellerer-Pirklbauer, A., Ribis, M., Hergarten, S., Winkler, G.: Wasserwirtschaftliche Aspekte von Blockgletschern in Kristallingebieten der Ostalpen - Speicherverhalten, Abflussdynamik und Hydrochemie mit Schwerpunkt Schwermetallbelastungen (RGHeavyMetal) - Final Report (2019)

Wagner, T., Pleschberger, R., Kainz, S., Kellerer-Pirklbauer, A., Krainer, K., Philippitsch, R., Winkler, G.: The first consistent inventory of rock glaciers and their hydrological catchments of the Austrian Alps. Austrian J. Earth Sci. 113(1), 1-23 (2020). https://doi.org/10.17738/ajes.2020.0001

Williams, M.W., Knauf, M., Caine, N., Liu, F., Verplanck, P.L.: Geochemistry and source waters of rock glacier outflow, Colorado Front Range. Permafr. Periglac. Process. 17, 13-33 (2006)

Winkler, G., Wagner, T., Pauritsch, M., Birk, S., Kellerer-Pirklbauer, A., Benischke, R., Leis, A., Morawetz, R., Schreilechner, M.G., Hergarten, S.: Identification and assessment of groundwater flow and storage components of the relict Schöneben Rock Glacier, Niedere Tauern Range, Eastern Alps (Austria). Hydrogeol. J. 24, 937-953 (2016)

Winkler, G., Wagner, T., Krainer, K., Ribis, M., Hergarten, S.: Hydrogeology of Rock Glaciers - Storage Capacity and Drainage Dynamics - an Overview (Гидрогеология горных ледников - емкость и динамика дренажа - обзор). In: Müller, L., Sychev, V.S. (eds.) Understanding and Monitoring in Soils and Water Bodies Novel Methods and Results of Landscape Research in Europe, Central Asia and Siberia (НОВЫЕ МЕТОДЫ И РЕЗУЛЬТАТЫ ИССЛЕДОВАНИЙ ЛАНДШАФТОВ В ЕВРОПЕ, ЦЕНТРАЛЬНОЙ АЗИИ И СИБИРИ), vol. II. FSBSI. Pryanishnikov Institute of Agrochemistry, Moscow (2018). https://doi.org/10.25680/8822.2018.82.81.168. Chapter II/7.1

Zurawek, R.: Internal structure of a relict rock glacier, Sleza Massif, southwest Poland. Permafr. Periglac. Process. 13, 29-42 (2002)

Publisher's Note Springer Nature remains neutral with regard to jurisdictional claims in published maps and institutional affiliations. 